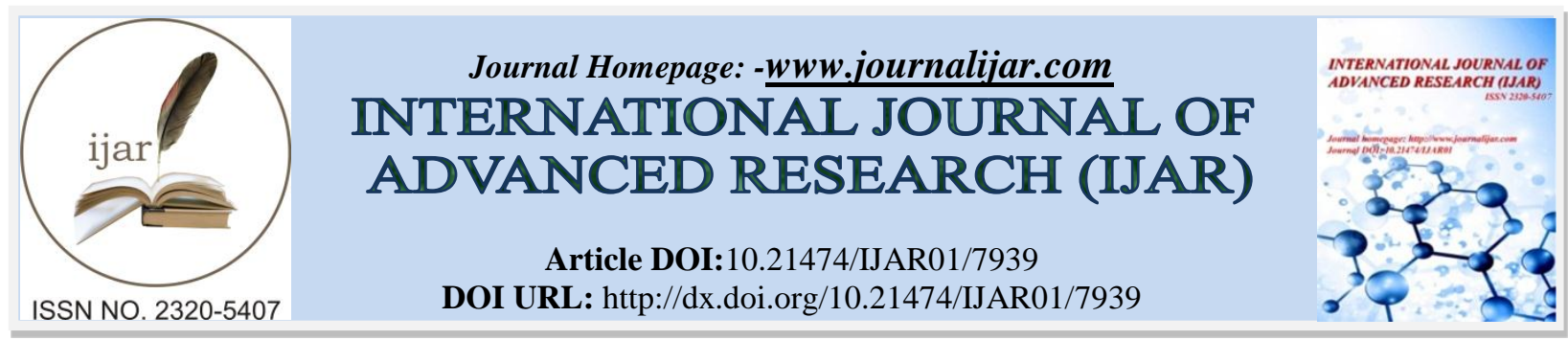

RESEARCH ARTICLE

\title{
EFFECT OF SODIUM CARBONATE, ERUCA SATIVA OIL, LAVENDER OIL AND ALOE VERA OIL ON LIVER IN BREAST CANCER INDUCED FEMALE RATS TREATED WITH DOXORUBICIN.
}

DiaaFarrag Ibrahim Ahmed.
Zoology department, Faculty of science, Al Azhar university, Nasr city, Cairo, Egypt.

\section{Manuscript Info}

\section{Manuscript History}

Received: 15 August 2018

Final Accepted: 17 September 2018

Published: October 2018

Keywords:-

Eruca sativa oil; Lavender oil; Aloe vera oil; breast cancer; Adriamycin; liver

\section{Abstract}

Background:Natural products like Eruca sativa,Aloe vera and lavender oils includes many antioxidants like isothiocyanates and flavonoids and vitamins in addition sodium carbonate is an alkaline material which used to alter the acidic medium of the cells. The previous natural products used to treat many diseases especially tumors Adriamycin is a chemical substance used to treat breast cancer but it is probably have side effects. The aim of the work is studying effect of Eruca sativaoil, lavenderoil,Aloe Vera oil and sodium carbonate on rat's liver that treated with Adriamycin after breast cancer induction. Materials and methods: thirty female albino rats were divided to sex groups, negative control, positive control, sodium carbonate group, Eruca sativa oil group, lavender oil group and Aloe Vera oil groups all groups except negative control are cancer induced with MCF7 cell line; all groups except negative control and positive control are Adriamycin treated the experiment was extended for one month the rats were sacrificed and serum is analyzed in addition to liver tissues were fixed and sectioned then stained and examined by light microscope.

Results: ANOVA show significant changes in total bilirubin, direct bilirubin, SGPT, and SGOT in serum of different treated group but on the liver tissue liver of sodium carbonate group shows destructed hepatocytes around the portal vein

Copy Right, IJAR, 2018,. All rights reserved.

\section{Introduction:-}

Consumption of green leafy vegetables reduces risk of several types of cancer and cardiovascular disease. The effect of these vegetables is attributed to a range of phytochemicals like flavonoids and glucosinolates. Eruca sativa is known as salad rocket (1).Secondary metabolites from plants have biological activity (2).Eruca sativa seed oil have antioxidant antimicrobial activity (3).Glucosinolates are nitrogen and sulfur-containing secondary metabolites found in Eruca sativa (4).

Aloe vera is a perennial succulent belonging to liliacea family and called healing plant or silent healer Aloe vera has burn and wound properties and anti-inflammatory and immunomodulatory effects (5). Aloe vera possess immunomodulatory anti-inflammatory UV protective, antiprotozoal and burn and wound healing properties (5). 


\section{Materials and Methods:-}

Chemicals:-

Doxorubicin hydrochloride (Adriadox $50 \mathrm{mg}$ in $25 \mathrm{ml}$ strile water production of Royal Medical PVT.LTD Khandelwal laboratories PVT.LTD.Calculations of Doxorubicin(DOXO) dose for rats was performed according to (6): briefly, Toconverta dose frommg $/ \mathrm{m} 2$ tomg $/ \mathrm{kginhuman}=75 \mathrm{mg} / \mathrm{m} 2(\mathrm{DOXO})$ in human $=75 \div 37=2.02 \mathrm{mg} / \mathrm{kg}$ in human. Toconvertthisdose fromhumantorats: $2.02 \mathrm{mg} / \mathrm{kginhuman}=2.02 \times 6.2=12.56 \mathrm{mg} / \mathrm{kginrats}$. Eruca sativa oil, Lavender oil and Aloe vera oil was produced by Everline Natural oils and cosmetics Co., $6^{\text {th }}$ October City. CairoEgypt saved in dark bottles and used fresh.

Induction of mammary tumors in rats:

All treated groups(4)and positive control are induced with breast cancer cell line MCF7 through injection of $1 \mathrm{ml}$ of the cell line intraperitoneally (i.p.) and left for one month for the development of breast cancer inside rats body.

Thirty female albino rats (Sprague Dawley) weighing about $160 \mathrm{gm} \pm 10 \mathrm{gm}$ (purchased from the National Research Center, Dokki, Cairo- Egypt, are divided equally into six groups: group one served as non-treated negative control; group two was a cancer positive control which were induced with breast cancer MCF7 cell line (each rat was injected with $1 \mathrm{ml}$ of this cell line 6 * $\mathbf{1 0}^{\mathbf{6}}$ cell (7); group three, rats of this group are administered with $1 \mathrm{ml}$ of sodium carbonate solution $1.2 \%$ solution(the dose in human used by some scientists was $12 \mathrm{~g} / \mathrm{L}$ ); rats of group four are administered with $1 \mathrm{ml}$ of Eruca sativa oil ؟; group five are administered with $1 \mathrm{ml}$ lavender oil. Group six was administered with $1 \mathrm{ml}$ Aloe vera oil notice that all used oils was watery extracted .

After that, rats of groups three, four, five and six are injected intraperitoneally with the chemotheraby doxorubicin hydrochloride $1 \mathrm{ml}(2 \mathrm{mg} / \mathrm{ml})$ solution $(7)$. Then at the second day of the administration of different treatments was orally through stomach tube and the administration duration was for one month then all rats are sacrificed.

At sacrifice, blood was collected in EDTA tubes for complete blood count analysis and the other parts of blood was collected and left to coagulate then blood was centrifuged at $3000 \mathrm{rpm}(\mathbf{8})$ for $10 \mathrm{~min}$ to obtain serum which prreserved at $-4{ }^{\circ} \mathrm{C}$ in ependorphs for later biochemical analysis.

Breast cancer cell line MCF7 was obtained from tissue culture VACSERA. Every rat was injected with 6 X10 ${ }^{6}$ cell according to preliminary studies.

\section{Histological sectioning:-}

Liver was collected from female rats and fixed in $10 \%$ formalin then put in wax blocks according to the method of (9), and stained with Prussian blue stain and Mallory trichrome stain then examined under $40 \mathrm{x}$ objectives of light microscope.

\section{Liver function tests:-}

Determinationof totalserumbilirubin level(mg/dl):-

Serum totalbilirubinwasdeterminedaccordingtothe method of (10)usingkitfromElitechdiagnostic Co.France.

Determinationofserumalanineaminotransferase(ALAT) Enzyme activity(U/L):

SerumALAT wasdeterminedaccordingtothemethodof (11)usingkitfromElitechdiagnosticCo. France.

Thekineticdeterminationofthealanineaminotransferase.

Determination of serum aspartate aminotransferase(ASAT) enzyme activity (U/L):-

Serum ASAT wasdeterminedaccordingtothemethodof (11)usingkitfromElitechdiagnosticCo. France.

Estimationofserumalkalinephosphatase(ALP)enzymeactivity(U/L):-

SerumALPwasdeterminedaccordingtothemethoddescribed by( 12 ) usingkit fromElitechdiagnostic Co. France.

Determinationof serumalbumin level(g/dl):-

Serum albuminwasdeterminedaccordingtothemethodof(13)using kitfromElitechdiagnostic Co. France. 
Determination of alkaline phosphatase activity :-

Gamma GT was determined according to (14) using PISHTAZ kit Germany

\section{Histological sectioning:-}

Livers were collected from female rats and fixed in $10 \%$ formalin then put in wax blocks. According to the method of Al Husseini and Demean 2004 and stained with hematoxylin and Eosin stain then examined under $10 \mathrm{X}$ and $40 \mathrm{x}$ objectives of light microscope.

\section{Results:-}

Table 1:-effect of sodium carbonate Aloe vera lavender and Eruca sativa on breast cancer induced and doxorubicin treated female albino rats

\begin{tabular}{|c|c|c|c|c|c|c|c|c|}
\hline Groups & $\begin{array}{l}\text { Negativ } \\
\mathrm{e} \\
\text { control } \\
\text { (a) }\end{array}$ & $\begin{array}{l}\text { Positive } \\
\text { control( } \\
\text { b) }\end{array}$ & $\begin{array}{l}\text { Sodium } \\
\text { carbonate( } \\
\text { c) }\end{array}$ & $\begin{array}{l}\text { Aloever } \\
\text { a oil (d) }\end{array}$ & \begin{tabular}{l}
\multicolumn{2}{l}{ Lavend } \\
er oil \\
(e)
\end{tabular} & $\begin{array}{l}\text { Eruca } \\
\text { sativa } \\
\text { (f) }\end{array}$ & $\begin{array}{l}\text { ANOVA } \\
\text { probabili } \\
\text { ty }\end{array}$ & $\begin{array}{l}\text { significan } \\
\text { ce }\end{array}$ \\
\hline $\begin{array}{l}\text { Total } \\
\text { bilirubin }(\mathrm{mg} / \\
\mathrm{dl}) \quad(\text { mean } \\
\pm \mathrm{SD})\end{array}$ & $\begin{array}{l}0.85 \\
\pm 0.07 \mathrm{ef}\end{array}$ & $\begin{array}{l}1.06 \\
\pm 0.11 \mathrm{c}\end{array}$ & $\begin{array}{l}1.65 \\
\pm 0.21\end{array}$ & $\begin{array}{l}0.8 \\
\pm 0.1 \mathrm{bc}\end{array}$ & $\begin{array}{l}0.85 \\
\pm 0.07 \mathrm{bc}\end{array}$ & $\begin{array}{l}0.56 \\
\pm 0.1 \mathrm{abc} \\
\mathrm{d}\end{array}$ & 0.001 & $* * *$ \\
\hline $\begin{array}{l}\text { Direct } \\
\text { bilirubin (mg/ } \\
\mathrm{dl}) \quad(\text { mean } \\
\pm \mathrm{SD})\end{array}$ & $\begin{array}{l}0.1 \\
\pm 0.05 \mathrm{c}\end{array}$ & $\begin{array}{l}0.166 \\
\pm 0.05 \mathrm{c}\end{array}$ & $\begin{array}{l}0.3 \\
\pm 0.1\end{array}$ & $\begin{array}{l}0.13 \\
\pm 0.05 \mathrm{c}\end{array}$ & $\begin{array}{l}0.13 \\
\pm 0.05 \mathrm{c}\end{array}$ & $\begin{array}{l}0.13 \\
\pm 0.05 \mathrm{c}\end{array}$ & 0.01 & $* *$ \\
\hline $\begin{array}{l}\text { SGPT(U/L) } \\
(\text { mean } \pm \text { SD) }\end{array}$ & $\begin{array}{l}51.66 \\
\pm 9.71 \mathrm{c}\end{array}$ & $\begin{array}{l}61.33 \\
\pm 4.72 \mathrm{c}\end{array}$ & $\begin{array}{l}81 \\
\pm 13\end{array}$ & $\begin{array}{l}44.33 \\
\pm 8.14 \mathrm{~b} \\
\mathrm{c} \\
\end{array}$ & $\begin{array}{l}55 \\
\pm 9.16 \mathrm{c}\end{array}$ & $\begin{array}{l}46.33 \\
\pm 16.44 \\
\mathrm{bc}\end{array}$ & 0.01 & $* *$ \\
\hline $\begin{array}{l}\text { SGOT(U/L) } \\
(\text { mean } \pm \text { SD) }\end{array}$ & $\begin{array}{l}167.66 \\
\pm 105.9 \\
7 \\
\end{array}$ & $\begin{array}{l}215.33 \\
\pm 22.85\end{array}$ & $\begin{array}{l}225 \\
\pm 59.77\end{array}$ & $\begin{array}{l}155.66 \\
\pm 28.5\end{array}$ & $\begin{array}{l}145 \\
\pm 28.16\end{array}$ & $\begin{array}{l}104.66 \\
\pm 2.30\end{array}$ & N.S. & N.S. \\
\hline $\begin{array}{l}\text { SAlp(U/L) } \\
(\text { mean } \pm \text { SD) }\end{array}$ & $\begin{array}{l}175 \\
\pm 46.13 \\
\end{array}$ & $\begin{array}{r}171.66 \\
\pm 30.92 \\
\end{array}$ & $\begin{array}{l}203.66 \\
\pm 47.64 \\
\end{array}$ & $\begin{array}{l}207 \\
\pm 52.94 \\
\end{array}$ & $\begin{array}{l}118.33 \\
\pm 14.5 \\
\end{array}$ & $\begin{array}{l}122 \\
\pm 33.77 \\
\end{array}$ & N.S & N.S \\
\hline $\begin{array}{l}\text { Albumin }(\mathrm{g} / \mathrm{dl} \\
(\text { mean } \pm \text { SD })\end{array}$ & $\begin{array}{l}4.36 \\
\pm 0.37\end{array}$ & $\begin{array}{l}3.7 \\
\pm 0.4 \text { ade } \\
\mathrm{f}\end{array}$ & $\begin{array}{l}3.5 \\
\pm 0.36 \text { adef }\end{array}$ & $\begin{array}{l}4.23 \\
\pm 0.7\end{array}$ & $\begin{array}{l}4.33 \\
\pm 0.48\end{array}$ & $\begin{array}{l}.23 \\
\pm 0.4\end{array}$ & 0.1 & $*$ \\
\hline $\begin{array}{l}\text { Gamma } \\
\text { GT(U/L) } \\
(\text { mean } \pm \text { SD }) \\
\end{array}$ & $\begin{array}{l}10.66 \\
\pm 1.15 \mathrm{~b} \\
\mathrm{c}\end{array}$ & $\begin{array}{l}15.33 \\
\pm 1.52\end{array}$ & $\begin{array}{l}16.33 \\
\pm 2.51\end{array}$ & $\begin{array}{l}12.66 \\
\pm 1.15\end{array}$ & $\begin{array}{l}7.63 \\
\pm 5.91 \mathrm{bc} \\
\mathrm{d}\end{array}$ & $\begin{array}{l}11 \\
\pm 1.73 \mathrm{bc}\end{array}$ & 0.01 & $* *$ \\
\hline
\end{tabular}

Data in table (1), Fig (1) show a significant increase in total bilirubin in sodium carbonate group when compared to positive control also there is a significant decrease in total bilirubin in Aloe vera oil group and lavender oil group and Eruca sativa comparing to positive control but when the treated groups compared together Eruca sativa show the most significant decrease than sodium carbonate and Aloe vera. where mean \pm SD for positive control group is (1.06 \pm 0.11$)$, sodium carbonate group (1.65 \pm 0.21$)$, Aloe vera group $(0.8 \pm 0.1)$, Lavender group $(0.85 \pm 0.07)$ and Eruca sativa group $(0.56 \pm 0.1)$ respectively.

Direct bilirubin as in table (1), Fig (2) show significant increase in sodium carbonate group comparing to positive control and comparing the treatments to gather.where mean $\pm \mathrm{SD}$ for positive control group is $(0.166 \pm 0.05)$, sodium carbonate group $(0.3 \pm 0.1)$, Aloe vera group $(0.13 \pm 0.05)$, Lavender group $(0.13 \pm 0.05)$ and Eruca sativa group $(0.13 \pm 0.05)$ respectively.

GPT as in table (1), fig (3) show significant increase in sodium carbonate group comparing to positive control and comparing treatments together, Aloe vera, and Eruca sativa show significant decrease to GPT comparing to positive 
control.where mean $\pm \mathrm{SD}$ for positive control group is (61.33 \pm 4.72$)$, sodium carbonate group $(81.00 \pm 13.00)$, Aloe

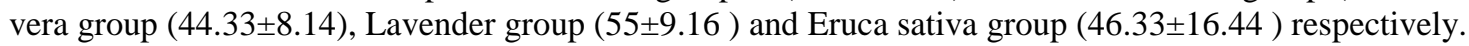

GOTas in table (1) and fig (4) did not show any significant changes in all groups.

As in table (1) and Fig (5) ALP did not show any significant changes in all groups.

As in table (1) and fig (6) Albumin show significant increase in Aloe vera, Lavender,Eruca sativaoil groups comparing to positive control.where mean $\pm \mathrm{SD}$ for positive control group is $(3.7 \pm 0.40)$, sodium carbonate group

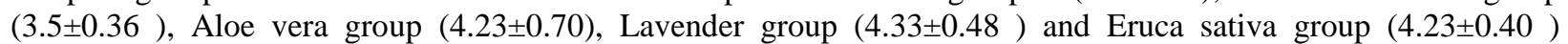
respectively.

As in Table (1) and fig (7)There is a significant decrease in gamma GT in lavender and Eruca sativa oil groups comparing to positive control.There is a significant decrease in gamma GT in lavender oil group comparing to sodium carbonate and Aloe vera, and a significant decrease in gamma GT in Eruca sativa comparing to Sodium carbonate group. where mean $\pm \mathrm{SD}$ for positive control group is (15.33 \pm 1.52 ), sodium carbonate group (16.33 \pm 2.51$)$, Aloe vera group (12.66 \pm 1.15$)$, Lavender group (7.63 \pm 5.91$)$ and Eruca sativa group (11 \pm 1.73$)$ respectively.

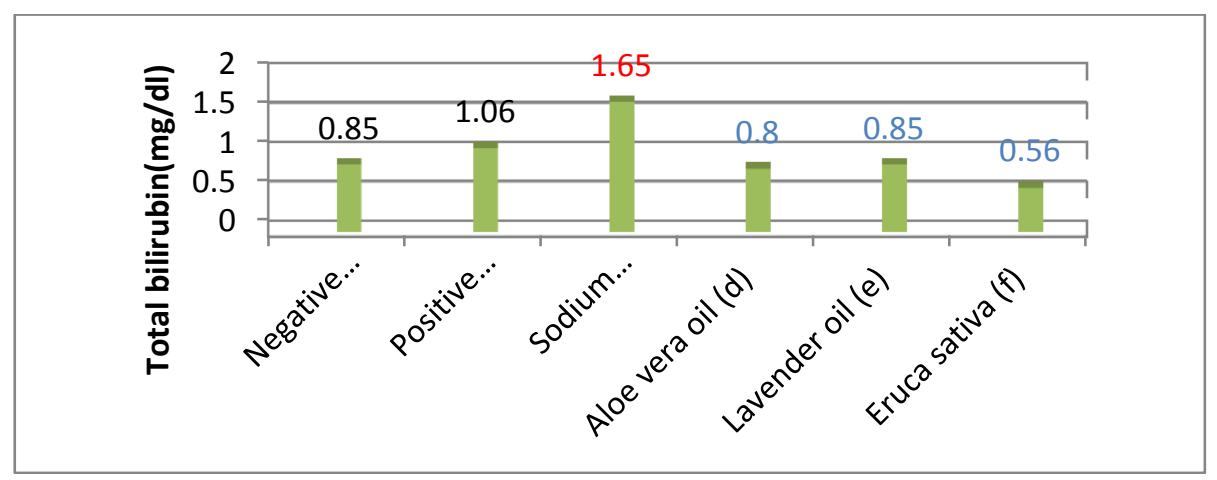

Fig 1:- Effect of Sodium carbonate, Aloe vara oil,Lavender oil and Eruca sativa oil on Total bilirubin in breast cancer induced and doxorubicin treated female albinorats

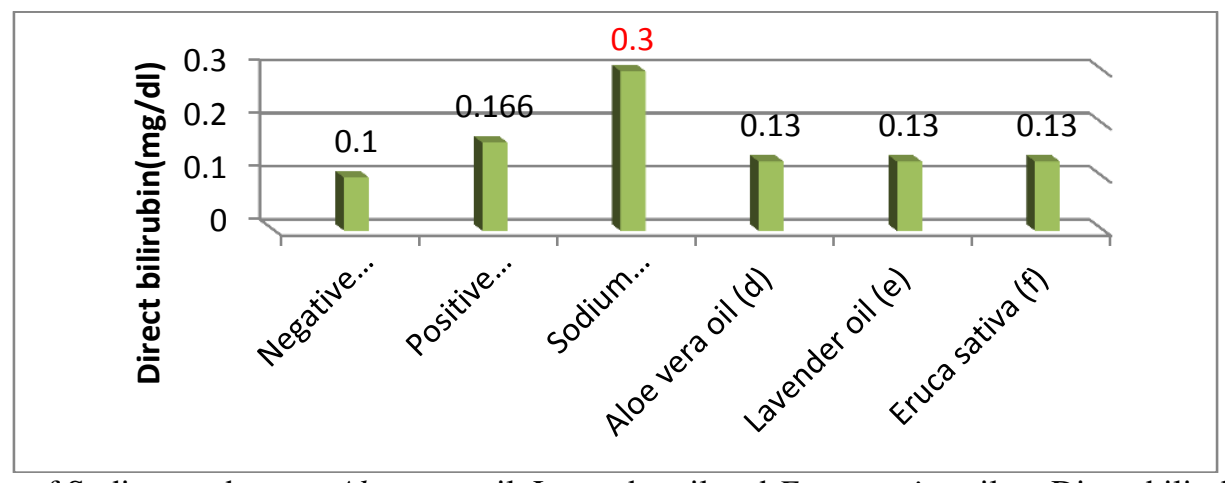

Fig 2:-Effect of Sodium carbonate, Aloe vera oil, Lavender oil and Eruca sativa oil on Direct bilirubin in breast cancer induced and doxorubicin treated female albinorats 


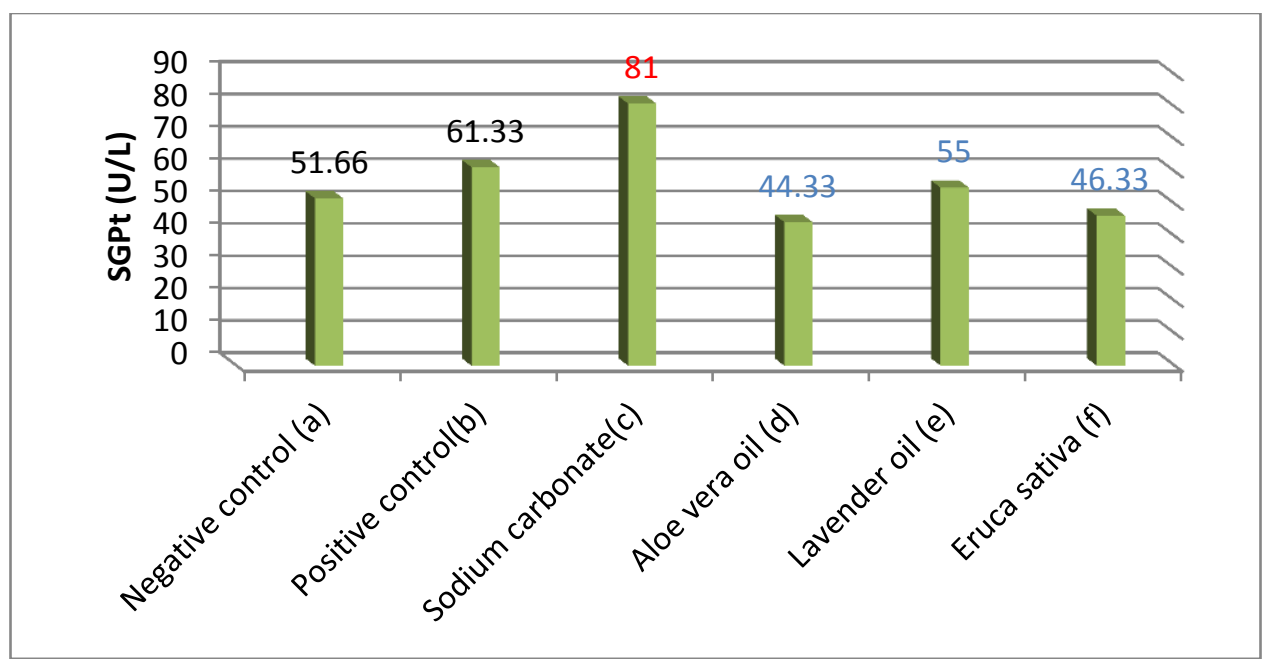

Fig 3:-Effect of Sodium carbonate, Aloe vera oil, Lavender oil and Eruca sativa oil on SGPT in breast cancer induced and doxorubicin treated femal albino rats

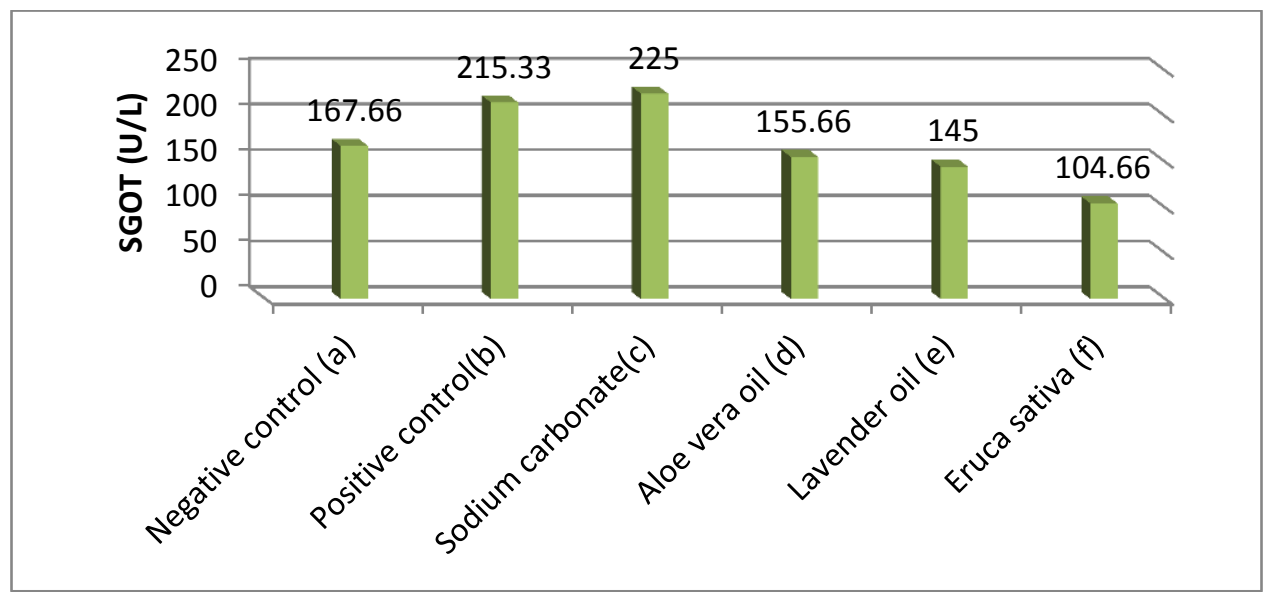

Fig 4:-Effect of Sodium carbonate, Aloe vera oil, Lavender oil and Eruca sativa oil on SGOT in breast cancer induced and doxorubicin treated female albino rats

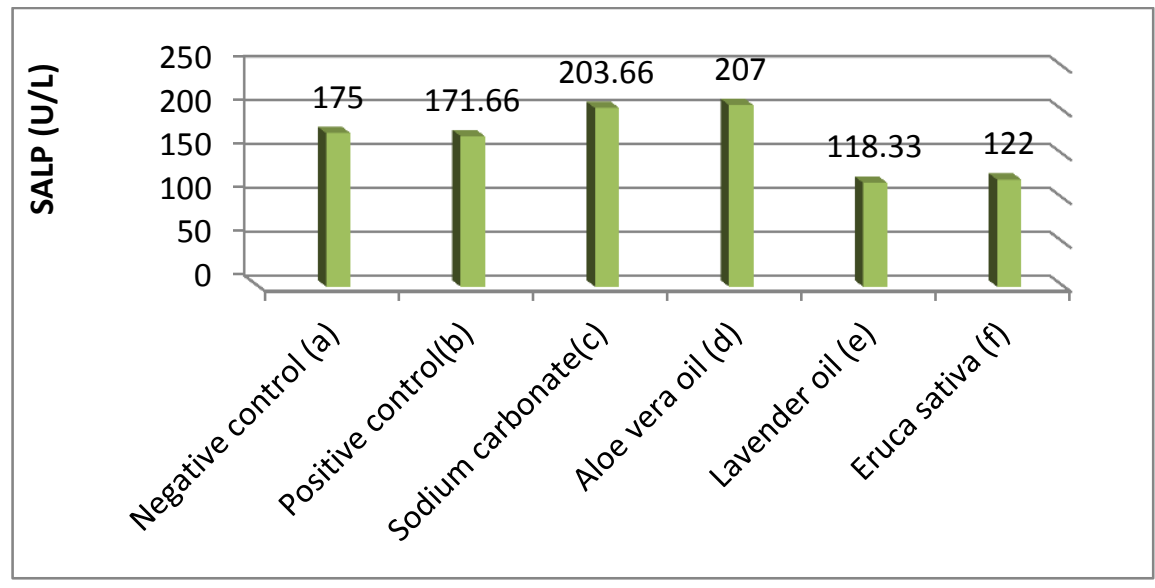

Fig 5:- Effect of Sodium carbonate, Aloe vera oil, Lavender oil and Eruca sativa oil on SALP in breast cancer induced and doxorubicin treated female albino rats 


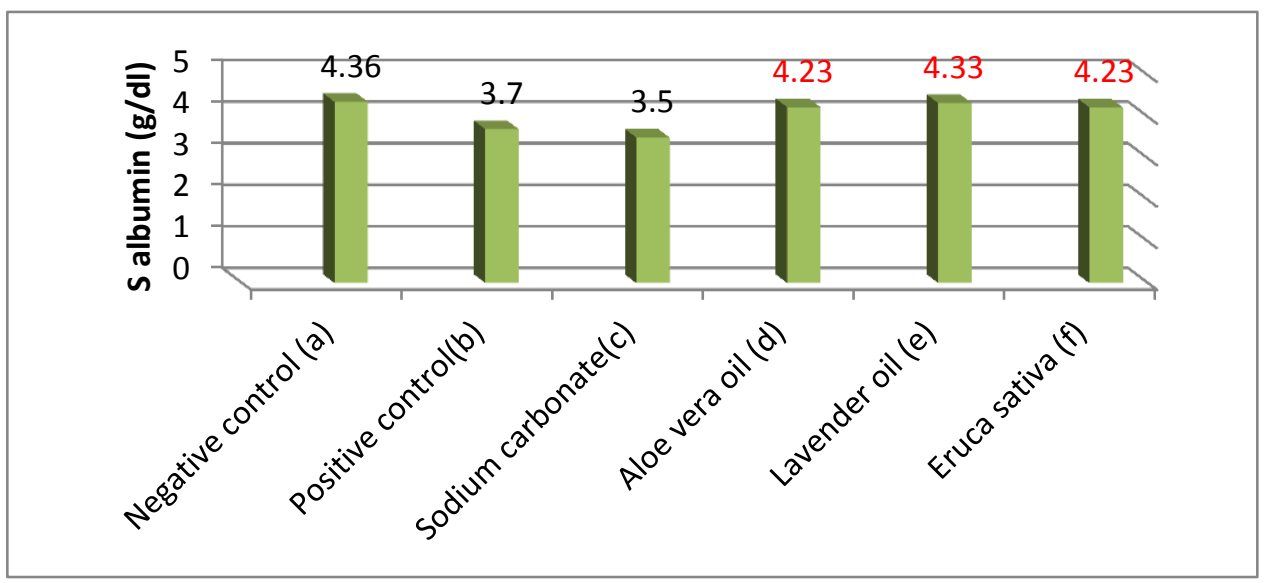

Fig 6:-Effect of Sodium carbonate, Aloe vera oil, Lavender oil and Eruca sativa oil on serum albumin in breast cancer induced and doxorubicin treated female albino rats

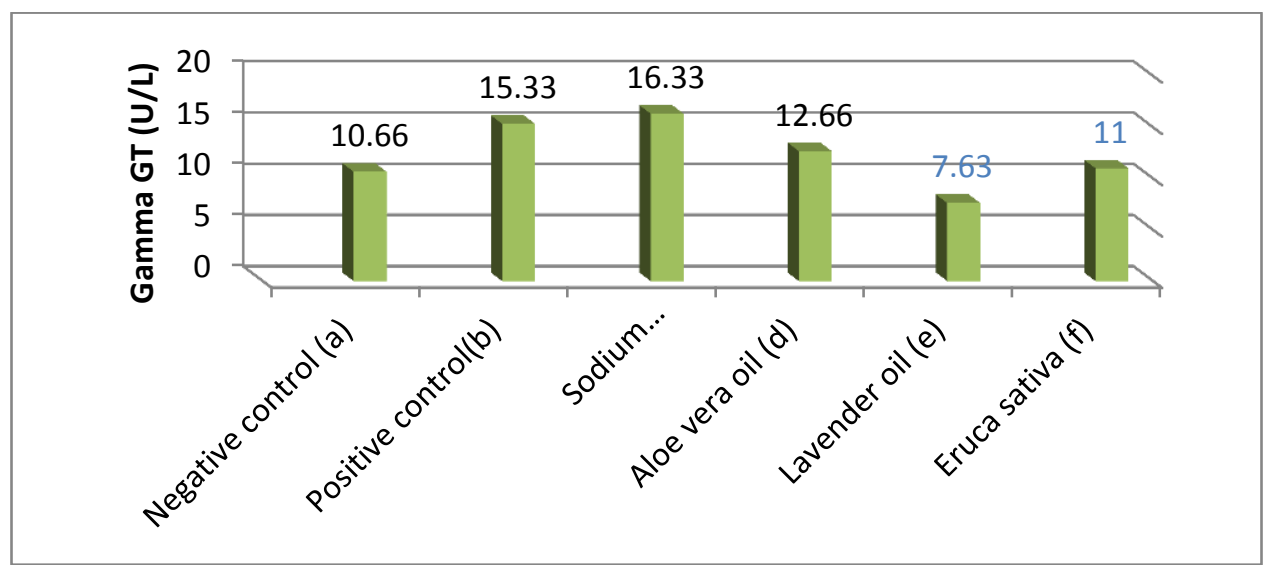

Fig 7:-Effect of Sodium carbonate, Aloe vera oil and Eruca sativa oil on serum Gamma GT in breast cancer induced and doxorubicin treated female albino rats

Note:-The red color for values on the columns means significant increase comparing to positive control.

Where, the blue color for values on the columns means significant decrease comparing to positive control.

Photomicrograph of negative control, positive control shows normal sections where liver of sodium carbonate group shows distracted hepatocytes around portal vein $(40 \mathrm{X})$. where other sections show normal sections in both 10X and 40X (H.\&E. stain). 


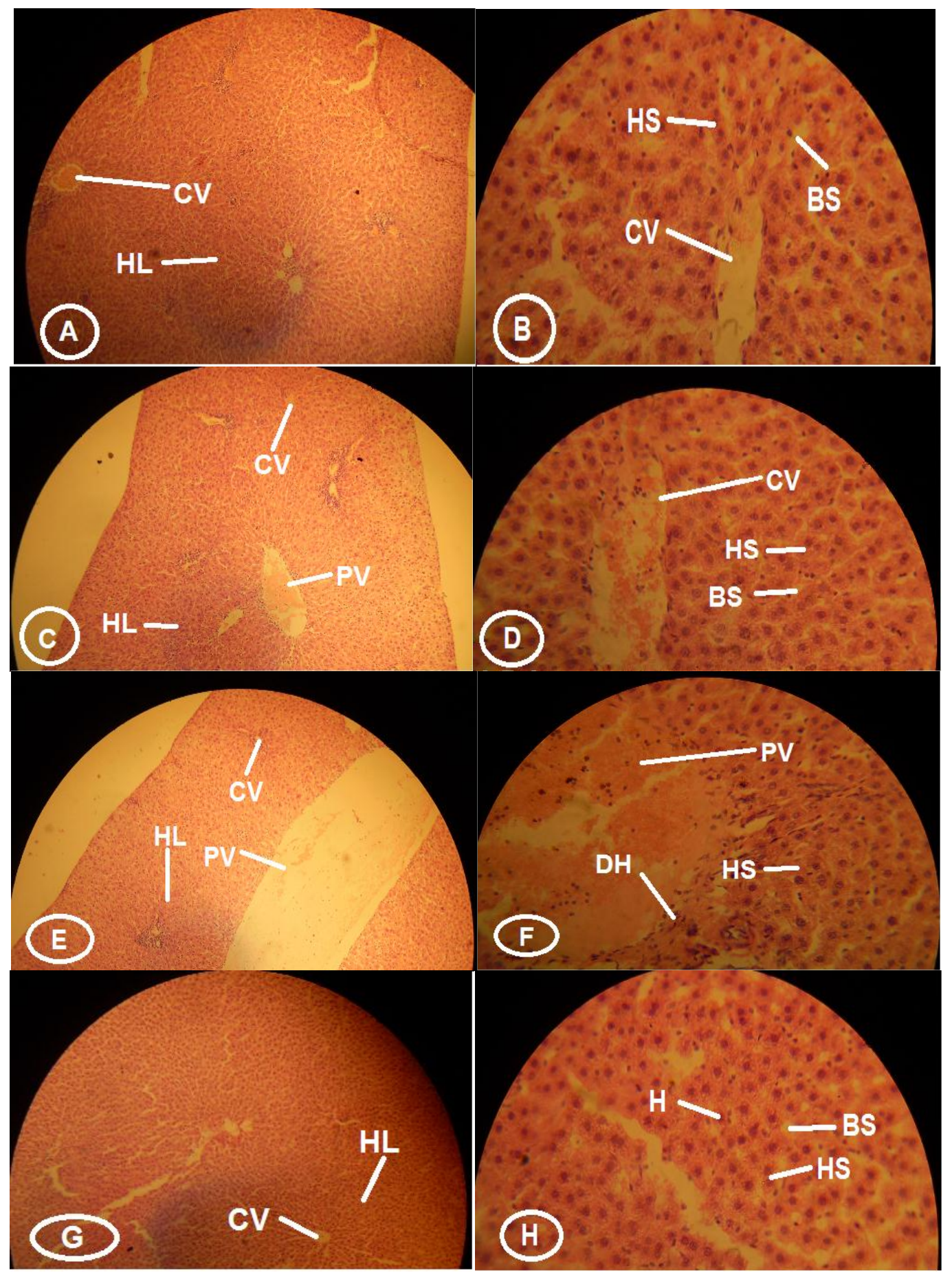




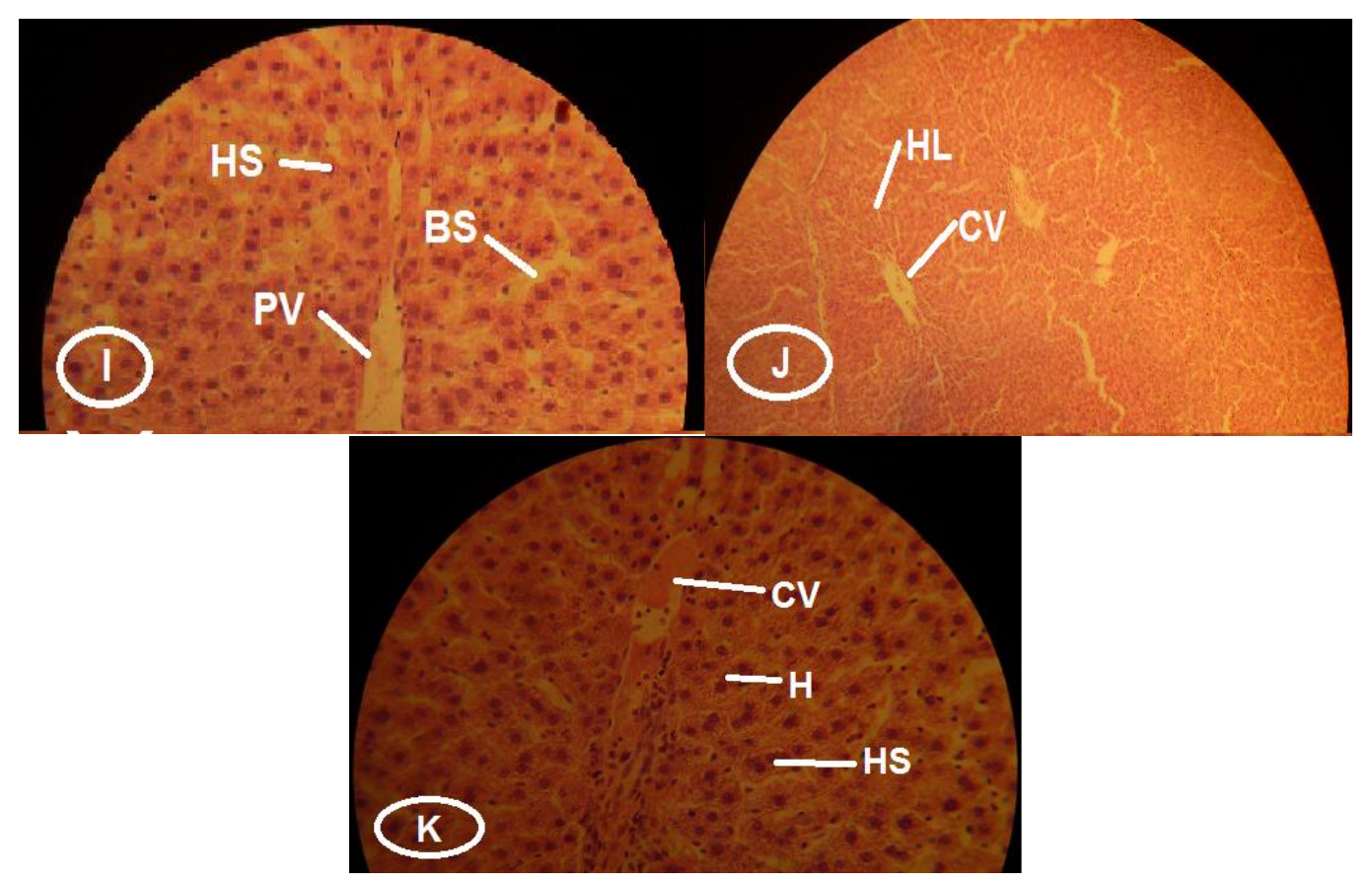

\section{Ligand:-}

1. Liver of negative control group $10 \mathrm{X} \mathrm{H \& E}$ stain shows normal section

2. Liver of negative control group $40 \mathrm{X} \mathrm{H \& E}$ stain shows normal section

3. Liver of Positive control liver 10 X H\&E stain shows normal section

4. Liver of Positive control 40 X H\&E stain shows normal section

5. Liver of Sodium carbonate group 10 X H\&E stain shows normal section

6. Liver of Sodium carbonate group $40 \mathrm{X}$ H\&E stain shows distracted hepatocytes around the portal vein

7. Liver of Erucastiva oil group 10 X H\&E stain shows normal section

8. Liver of Erucastiva oil group $40 \mathrm{X} \mathrm{H} \& \mathrm{E}$ stain shows normal section

9. Liver of Aloe vera oil group $40 \mathrm{X} \mathrm{H} \& \mathrm{E}$ stain shows normal section

10. Liver of Lavender oil group 10 X H\&E stain shows normal section

11. Liver of Lavender oil group 40 X H\&E stain shows normal section

$\mathrm{CV}=$ central vein; $\mathrm{HL}=$ Hepatic lobule; $\mathrm{HS}=$ Hepatic strand; $\mathrm{BS}=$ Blood sinusoid; $\mathrm{PV}=$ Portal vein; $\mathrm{H}=$ Hepatocytes

\section{Discussion:-}

Consumption of green leafy vegetables reduces risk of several types of cancer and cardiovascular disease. The effect of these vegetables is attributed to a range of phytochemicals like flavonoids and glucosinolates. Eruca sativa is known as salad rocket (1).Secondary metabolites from plants have biological activity (2).The several biologically active compounds present in plants work together to produce greater effect than that of a single chemical (15).

The plant Eruca sativa is widely distributed all over the world and originated in the Mediterranean region (16) Eruca sativa seed oil have antioxidant antimicrobial activity (3) Inhibition of melanoma proliferation (17).Eruca sativa oil has bioactive substances like allyl isothiocyanate, phenyl ethyl isothiocyanate and sulphoraphane which have antimelanoma activity (18).

Isothiocyanates reduce activation of carcinogens and increase their detoxification exhibiting anticarcinogenic activity (19) and (20). Isothiocyanates act through two ways apoptosis and exhibit anticancer activity by multiple pathways including oxidative stress (21) and (22) inhibition of cell cycle progression (23) and (24), angiogenesis (25) and MAPK signaling (26) and (27)

Isothiocyanates disables the glutathione (GSH) antioxidant system effectively and cause Ros Accumulation in transformed cells due to their active ros output. Their excessive ros cause oxidative mitochondrial damage, 
cytochrome Crelease in activation of redox- sensitive molecules (GXP) and massive ell death, isothiocyanaes may induce cell cycle arrest (G1 and G2/M pases) indifferent phases in a cell line dependent manner.

Isothiocyanates may also induce apoptosis through a caspase-3- dependent MAPK mechanism based on JNK and caspase-3-depeent mechanism. It induces rapid and transient induction of caspase 3 activity and stimulatesproteolytic cleavage of poly-(ADP-rbose) polymerase resulting into caspase activionand precedes DNA fragmentation.Glucosinolates are nitrogen and sulfur-containing secondary metabolites found in Erucasativa(4).

Glucosinolates are hydrolyzed by endogenous thioglucosidases which called myrosinases to produce a wide range of degradation products (isothiocyanates, nitriles, epithiocyanates, oxazolidine-thiones and thiocyanates) with diverse biological activities (28) Frequent consumption of vegetables with high glucosinolates content is associated with a lowered risk of cancer and cardiovascular disease . (28)

The most prominent glucosinolates present in leaves of eruca sativa is glucoraphanin which gives rise upon hydrolysis to sulphoraphane; this later degradation product is recognized as the most effective compound which promotes the liver to produce enzymes that detoxify cancer -causing chemicals, especially those connected to chemically induced breast cancer and colon cancer (28).

Solvent extracts from seed oil from Eruca sativa (Rocket salad) significantly reduced the tumor growth comparable to the control. Remarkably the seed oil inhibited melanoma growth and angiogenesis in mice without any major toxicity (17).

Khoobchandani et al., (2011)Reported that Eruca sativa seeds are relevant source of antioxidant protection, the iso thiocyanates found in seed oil play important role in inhibition of proliferation of cancerous cells.Isothiocyanates increase detoxification proteins and expression of antioxidant such as glutathione s- transferase (GST) and NAD (P) $\mathrm{H}$ : quinine oxidoreductase (29). The isothiocyanatesulforaphane inhibit histone de acetylase which alter gene expression which could alter tumorigenesis (30).

Khoobchandani et al., (2011) reported that glucosinolate breakdown products can influence the initiation and progression of carcinogenesis and they also appear to influence apoptotic responses to chemotherapeutic agents.

Aloe vera is a perennial succulent belonging to liliacea family and called healing plant or silent healer Aloe vera has burn and wound properties and anti-inflammatory and immunomodulatory effects (5). Aloe vera possess immunomodulatory anti-inflammatory UV protective, antiprotozoal and burn and wound healing properties (5).

Perhaps its survival in a harsh environment encourages people to believe that Aloe vera has antibiotic and wound healing effects. It is possible that aloe vera activate anticancer immunity and produce therapeutic benefits in terms of stabilization of disease and survival in patients with advanced solid tumors.Aloe vera contains glycoproteins, anthraquinones, Saccharides and low molecular weight substances. Antraquinones like aloe-emodin ,aloetic acid, abin, anthranal, barbaloin, isobarbaloin, emodin and ester of cinnamic acid, saccharides like cellulose, glucose, mannose, acetylated mannan, aldopentose, glucomannan, acetylated glucomannan, galactogalacturan, glucogalactomanan and galactoglucoarabinomannan, vitamins like B1,B2,B6, C, B-carotene, choline, folic acid, alfa-tocopherol, enzymes like amylase, catalase,carboxypeptidase, cyclooxidase, lipase, oxidase in addition to low molecular weight substances like cholesterol, arachidonic acid, gibberellin, lectin-like substace, lignns, salicylic acid beta-sioseo,teroids triglycerides and uric acid cited by(5).

Despite lack of data on the effect of bicarbonate therapy, many attempts to alkalinize blood with intravenous administration of sodium bicarbonate as part of the treatment of sepsis so, the benefit of bicarbonate administration in metabolic acidosis in sepsis is controversial and remains a matter of debate in clinical practice (31).

Metabolic acidosis can be the result of either a primary increase in hydrogen ion $(\mathrm{H}+)$ or reduction in carbonate concentration. Bicarbonate is the main form of $\mathrm{co} 2$ in human body and can be estimated from $\mathrm{PH}$ and $\mathrm{PCO} 2$ normal $\mathrm{PH}$ range is $7.35-7.45$ and normal bicarbonate is $21-28 \mathrm{~m} \mathrm{Eq} / \mathrm{L}$. blood $\mathrm{PH}$ is reduced acidosis when $\mathrm{CO} 2$ quantity is reduced or when quantity of base as bicarbonate $\mathrm{HCO} 3$, increase in blood. Bicarbonate is secreted and absorbed again (conservation) from the kidneys in response to $\mathrm{PH}$ changes and is commonly encountered as sodium bicarbonate (NaHCo3). Bicarbonate administration can stimulate superoxide formation, increaseproinflammatory 
cytokine release and enhance apoptosis and may also result in paradoxical intracellular acidosis due to generation of co2. In clinical use, bicarbonate administration can cause volume expansion and hypernatremia but can also result in reduced blood pressure and cardiac out but and increase mortality. Although administration of bicarbonate aims to normalize extracellular and intracellular PH and improve outcome (32).

Several studies suggest that this approach is overly simplistic (33) and the impact of bicarbonate administration on restoring hemodynamics, reducing vasopressor requirements and improving clinical outcomes is unknown (34)

Effect of chronic Adriamycin treatment on liver tissue of male and female rats were studied and found that concerning the components of oxidative defense system in male rats showed reductions in the activity of factors of the glutathione system in liver tissue. The activity of Se-dependent glutathione peroxidase sharply decreased only in liver. The decreased activity of the cytochrome reductase was found in liver of male rats.Adriamycin is an anthracycline antibiotic that possesses excellent antitumor activity against a variety of cancers,.(35) there is a large evidence indicating that free radical stress is increased due to presence of Adriamycin in many compartments of mammalian cell e.g. the mitochondria (36). In addition, Adriamycin stimulated oxygen radical production was shown to occur in intact cells, for example in hepatocytes (37).

Hepatotoxicity was found both in humans (38) and rabbits (39) following chronic ADM treatment. The total capacity of the cellular systems that detoxify reactive oxygen species or free, radical-drug metabolites appeared to be higher in female rats liver as compared to male (40).

Liver is relatively resistant to Adriamycin toxicity, have high levels of glutathione and glutathione peroxidase and exhibited a sharp decline in non - protein thiol concentrations within 1-3 hr. with rebound by $6 \mathrm{hr}$ after Adriamycin.

The hepatoprotective and antioxidant effect of an ethanolic extract of "Rocket" Eruca sativa L. on liver injury induced by carbon tetrachloride was investigated by (41) he found a fall in the levels of total protein and increased level of malondy aldehyde concentration Eruca sativa extract prevent $\mathrm{CCl} 4$ induced hepatic injury and oxidative stress by its potent antioxidant activity in rats.

Daily oral administration of Eruca sativa seed oil 2 weeks before or after diabetes induction ameliorated hyperglycemia, improves lipid profile, blunted the increase in malondialdehyde and 4-hydroxynonenal and stimulated theGsh production in the liver of alloxan treated rats (42).

Oxidative stress in cells and tissues results from the increase generation of reactive oxygen species and /or from decreases in antioxidant defense potential (43). Elevated generation of free radicals resulting in the consumption antioxidant defense components may lead to disruption of cellular functions and oxidative damage to membranes and probably enhance susceptibility to lipid peroxidation (44).

In physiological conditions a wide spread antioxidant defense system protects the body against the adverse effects of free radical production (45).Aloe vera is a perennial plant belonging to the family liliaceae which includes about 360 species (46)

Aloe vera is a chemically ill- defined extract of the Aloe barbadensis miller plant. Aloe vera contains bio active substances (47) (1). It has anti-inflammatory, analgesic, liver protective, antiaging and laxative properties (15). These effects are due to radical scavenging inhibition of COX-2, and immunomodulatory effects. It consider antiaging drug in western European countries (48). The Aloe vera preparation has caused the acute hepatitis.

Aloe vera the dried extract from the leaves of Aloe barbadensis miller plantconains several alkaloids that may induce or block hepatic enzyme systems such as cytochrome P450 as well the enzymes of ethanol metabolism (49) this interference with detoxification processes leading to dose related liver damage or direct cytotoxic effect of Aloe (50) (7) or biotransformed constituents (51). Several compounds present in Aloe vera may interact with immune system( 52) (10) which may inhibit the release or cause the rapid detoxification of reactive oxygen species (43)(12) 


\section{Conclusion:-}

1. Eruca sativa, Aloe vera and lavender oils decrease bilirubin.

2. Sodium carbonate increase total and direct bilirubin.

3. Sodium carbonate increase Gpt.

4. Erucasativa, Aloevera and lavender oils increase albumin.

5. Eruca sativa, Aloe vera and lavender oils decrease gamma GT comparing to sodium carbonate.

6. Erucasativa ,Aloe vera and lavender oils improve liver in Adriamycin treated rats induced with breast cancer.

7. Sodium carbonate has destructive effect on hepatocytes

\section{Recommendation:-}

Usage Eruca sativa, Aloe vera and lavender oils as complementary food with Adriamycin treated ,breast cancer patients.

\section{References:-}

1. Jin J, Koroleva o A, Gibson T, Swanston J, Magan J, Zhang Y, Rowland I R \& Wagstaff C(2009):Analysis of Phytochemical Composition and Chemoprotective Capacity of Rocket (Eruca sativa and Diplotaxistenuifolia) Leafy Salad Following Cultivation in Different Environments. J. Agric. Food Chem. 57 (12), pp 5227-5234.

2. Duke S O (1990):Natural pesticides from plants. In: Janick J, Simon JE, editors. Advances in new crops. Portland, OR: Timber Press. pp. 511-7.

3. Khoobchandani M, Ojeswi BK, Ganesh N, Srivastava MM, GabbaniniS, Matera R. (2010):Antimicrobial properties and analytical profile of traditional Eruca Sativa seed oil: Comparison with various aerial and root plant extracts. Food Chem.120:217-24.

4. Tommaso,Cataldi R I, Alessandra R, Filomena L \&Sabino A B(2007): Naturally occurring glucosinolates in plant extracts of rocket salad (Eruca sativa L.) identified by liquid chromatography coupled with negative ion electrospray ionization and quadrupole ion-trap mass spectrometry, Volume 21, Issue 14,30 July , Pages 23742388

5. Seongwon C\&Myung-Hee CA (2003):review on the relationship between aloe vera components and their biologic effectsSeminars in Integrative MedicineVolume 1, Issue 1, March, Pages 53-62

6. Hidalgo M, Bruckheimer E, Rajeshkumar N V, Garrido-Laguna I, De Oliveira E, Rubio-Viqueira B, ... \&Sidransky, D. (2011). A pilot clinical study of treatment guided by personalized tumorgrafts in patients with advanced cancer. Molecular cancer therapeutics, 10(8), 1311-1316.

7. El Shahat B E, MSC. thesis (2013): Effect of bee venom on some physiological parameters and tumor markers in cancer infected rats. Faculty of science AlAzhar university Cairo,Egypt P. 47

8. Rodak F P (1995). Routin laboratory evaluation of blood cells and bone marrow. Diagnostic hematology, 125129.

9. Al-HussainiA H \&demian E S (2004): Practical animal biology, volume one twenty seventh edition Dar AlMaaref; pp. 280-290.

10. Dutt M K, Murphy G M, \& Thompson R P H (2003):"Unconjugated bilirubin in human bile: the nucleating factor in cholesterol cholelithiasis?." Journal of clinical pathology 56(8): 596-598.

11. Bergmeyer H U, Horder M \&Rej R (1986): Approved Recommendation (1985) on IFCC methods for the measurement of catalytic concentration of enzymes. 3. IFCC method for alanine aminotransferase (L-alanine-2oxoglutarate aminotransferase, EC-2612). Journal of Clinical Chemistry and Clinical Biochemistry, 24(7), 481495.

12. Bergmeyer, H U, Büttner H, Hillmann G, Kreutz F H, Lang H \& Laue D (1972): Recommendations of the german society for clinical chemistry. J ClinChemClinBiochem, 10, 281-91.

13. Doumas B T, Watson WA \& Biggs H G (1971): Albumin standards and the measurement of serum albumin with bromcresol green. ClinicaChimicaActa, 31(1), 87-96.

14. BablockW et al.(1988):A General Regression Procedure for Method Transformation. J ClinChemClin Biochem.26:783-790

15. Lin JH\& Lu AY(1997):Role of Pharmacokinetics and Metabolism in Drug Discovery and Development. PharmacolRev. ;49:403-49. [PubMed]

16. Zeven A C\& de Wet J M 2nd ed. (1982):Wageningen: Centre for Agricultural Publishing and Documentation;. Dictionary of cultivated plants and their regions of diversity; p. 107.

17. Khoobchandani M, Ganesh N, Gabbanini S, Valgimigli L, Srivastava MM(2011): Phytochemical Potential of Eruca Sativa for inhibition of melanoma tumor growth. Fitoterapia.82:647-53. [PubMed] 
18. Ojeswi BK, Khoobchandani M, Hazra DK\&Srivastava MM(2009):Green chemicals: Prospects and future in designing new drugs for cancer. Int J Wastewater Treat Green Chem. ;1:17-22.

19. Zhang Y\&Talalay P(1994):Anticarcinogenic activities of organic isothiocyanates-chemistry and mechanisms. Cancer Res. ;54:1976-81s. [PubMed]

20. Hecht SS(1995):Chemoprevention by isothiocyanates. J Cell Biochem. 22:195-209.[PubMed]

21. Trachootham D, Zhou Y, Zhang H, Demizu Y, Chen Z, Pelicano H et al. (2006): Selective killing of oncogenically transformed cells through a ROS-mediated mechanism by â-phenylethylisothiocyanate. Cancer Cell. ;10:241-52. [PubMed]

22. Xu K\&Thornalley PJ(2001):Involvement of GSH metabolism in the cytotoxicity of the phenethylisothiocyanate and its cysteine conjugate to human leukaemia cells in vitro . BiochemPharmacol. 61:165-77. [PubMed]

23. Zhang YS, Tang L\& Gonzalez V(2003):Selected isothiocyanates rapidly induce growth inhibition of cancer cells. Mol Cancer Ther. 2:1045-52. [PubMed]

24. Zhang RF.Loganathan S, Humphreys I\& Srivastava S K (2006):Benzyl isothiocyanate-induced DNA damage causes G2/M cell cycle arrest and apoptosis in human pancreatic cancer cells. J Nutr. 136:2728-34. [PubMed]

25. Xiao D\& Singh SV( 2007):Phenethylisothiocyanate inhibits angiogenesis in vitro and ex vivo. Cancer Res. ;67:2239-46. [PubMed]

26. Xu CJ, Shen GX, Yuan XL, KimJH, Gopalkrishnan, A\&Keum YS et al. (2006):ERK and JNK signalling pathways are involved in the regulation of activator protein 1 and cell death elicited by three isothiocyanates in human prostate cancer PC-3 cells. Carcinogenesis. ;27:437-45. [PubMed]

27. Hu R, Kim BR, Chen C, Hebbar V\& Kong ANT ( 2003):The roles of JNK and apoptosis signalling pathways in PEITC mediated responses in human HT-29 colon adenocarcinoma cells. Carcinogenesis. 24:1361-7. [PubMed]

28. Kliebenstein DJ, Kroymann J, Brown P, Figuth A, Pedersen D, Gershenzon J, Mitchell-Olds T(2001):Genetic control of natural variation in Arabidopsis glucosinolateaccumulation.Plant Physiol. ; 126: 811.

29. Nakamura Y, Morimitsu Y, Uzu T,Ohigashi H, Murakami A, Naito Y,Nakagawa Y, Osawa T, Uchida K (2000): A glutathione S-transferase inducer from papaya: rapid screening, identification and structure-activity relationship of isothiocyanates. Cancer Lett 157:193-200

30. Myzak MC, Hardin K, Wang R, Dashwood RH, Ho E. (2006):Sulforaphane inhibits histone deacetylase activity in BPH-1, LnCaPand PC-3 prostate epithelial cells. Carcinogenesis 27:811-819

31. Dimitrios V, Vasilios K, Nikolaos K, Charalampos P\& Menelaos K (2015):The Use of Sodium Bicarbonate in the Treatment of Acidosis in Sepsis: A Literature Update on a Long Term DebateCrit Care Res Pract. doi: $10.1155 / 2015 / 605830$.

32. Carious A, Vinsonneau C \&Dhainaut J F(2004):Adjunctive therapies in sepsis: an evidence-based review. Critical Care Medicine. ;32(11):S562-S570. doi: 10.1097/01.ccm. [PubMed] [Cross Ref]

33. Forsythe S M \& Schmidt G A( 2000): Sodium bicarbonate for the treatment of lactic acidosis. Chest;117(1):260-267. doi: 10.1378/chest.117.1.260. [PubMed][Cross Ref]

34. Dellinger R P, Levy M M, RhodesA et al. (2013):Surviving sepsis campaign: international guidelines for management of severe sepsis and septic shock: 2012. Critical Care Medicine. 41(2):580-637. doi: 10.1097/ccm.0b013e31827e83af.[PubMed] [Cross Ref]

35. HANDA K\& SATO S. (1976): Stimulation of microsomal NADPH oxidation by quinonegroupcontaining anticancer chemicals. GANN Japanese Journal of Cancer Research, 67(4), 523-528.

36. Karash E D\& Novak R.F(1983): inhibitory effects of anthracenedione antineoplastic agents on hepatic and cardiac lipid peroxidation J PharmacolExp Ther.226:500-506

37. Babson J R, Abell N S \& Reed D J (1981): Protective role of the glutathione redox cycle against adriamycinmediated toxicity in isolated hepatocytes. Biochemical pharmacology, 30(16), 2299-2304.

38. Kun L E, \&Camitta B M (1978):Hepatopathy following irradiation and adriamycin. Cancer, 42(1), 81-84.

39. Van Vleet J F \&Ferrans V J (1980): Clinical and pathologic features of chronic adriamycintoxicosis in rabbits. American journal of veterinary research, 41(9), 1462-1469.

40. Pascoe G A \& Reed D J (1987): Vitamin E protection against chemical-induced cell injury: II. Evidence for a threshold effect of cellular $\alpha$-tocopherol in prevention of adriamycin toxicity. Archives of biochemistry and biophysics, 256(1), 159-166.

41. Alqasoumi S (2010): Carbon tetrachloride-induced hepatotoxicity: Protective effect of'Rocket'Eruca sativa L. in rats. The American journal of Chinese medicine, 38(01), 75-88.

42. El-MissiryM A, \& El Gindy A M (2000): Amelioration of alloxan induced diabetes mellitus and oxidative stress in rats by oil of Eruca sativa seeds. Annals of Nutrition and Metabolism, 44(3), 97-100. 
43. Singh RP, Dhanalakshmi S\&Rao A R(2000):Chemomodulatory action of Aloe vera on the profiles of enzymes associated with carcinogen metabolism and antioxidant status regulation in mice. Phytomedicine. 7:209-219. [PubMed]

44. Baynes, JW (1991): Role of oxidative stress in development of complications in diabetes. Diabetes, 40, 405412.

45. Halliwell B\&Gutterridge JMC(1984): Lipid peroxidation, oxygen radicals, cell damage and antioxidant therapy.The Lancet, 323(8391), 1396-1397

46. Klein AD\&Penneys N (1988): Aloe vera. J Am AcadDermatol, , 18, 714-720.

47. Andallu B \&Varadacharyulu N C (2003): Antioxidant role of mulberry (Morusindica L. cv. Anantha) leaves in streptozotocin-diabetic rats. Clinicachimicaacta.338(1), 3-10.

48. Christian R, Annemarie M, Peter S, Wolfgang K, \& Robert H(2005):Acute hepatitis induced by an Aloe vera preparation: A case report World J Gastroenterol. Jan 14; 11(2): 303-304.Published online 2005 Jan 14. doi:10.3748/wjg.v11.i2.303

49. Chung JH, Cheong JC, Lee JY, Roh HK, \&Cha YN(1996):Acceleration of the alcohol oxidation rate in rats with aloin, a quinone derivative of Aloe. Biochem Pharmacol.52:1461-1468. [PubMed]

50. Avila H,Rivero J, Herrera F\&Fraile G (1997):Cytotoxicity of a low molecular weight fraction from Aloe vera (Aloe barbadensis Miller) gel. Toxicon. 35:1423-1430.[PubMed]

51. Mueller SO, Stopper H, Dekant W(1998):Biotransformation of the anthraquinonesemodin and chrysophanol by cytochrome P450 enzymes. Bioactivation to genotoxic metabolites. Drug MetabDispos. ;26:540-546. [PubMed]

52. Hart LA, van Enckevort PH, van Dijk H, Zaat R, de Silva KT\&Labadie R P(1988):Two functionally and chemically distinct immunomodulatory compounds in the gel of Aloe vera. J Ethnopharmacol. 23:61-71. [PubMed] 